\title{
"Hope" and "Change": An Empirical Study on the Eight Provisions of the CPC Rectification Movement Based on Authoritative Data Released by the Central Commission for Discipline Inspection Supervision Website
}

\author{
Xudong Qi \\ School of Government, Beijing Normal University, Beijing, China \\ Email:664259569@qq.com
}

How to cite this paper: Qi, X.D. (2017) "Hope" and "Change": An Empirical Study on the Eight Provisions of the CPC Rectification Movement Based on Authoritative Data Released by the Central Commission for Discipline Inspection Supervision Website. Open Journal of Social Sciences, 5, 338-349.

https://doi.org/10.4236/jss.2017.55023

Received: May 4, 2017

Accepted: May 21, 2017

Published: May 24, 2017

Copyright $\odot 2017$ by author and Scientific Research Publishing Inc. This work is licensed under the Creative Commons Attribution International License (CC BY 4.0).

http://creativecommons.org/licenses/by/4.0/

\section{c) (†) Open Access}

\begin{abstract}
Since 18th CPC National Congress, the anti-corruption campaign shows a new political life in China. Based on the data from 2015 to July 2016, this paper analyzes the effectiveness and trend of the implementation of the eight provisions from the following three perspectives. The number of violations of cadres and their administrative level was significantly negatively correlated. The main purpose of the eight provisions is to build a low administrative level of anti-corruption strategy. The township level cadres are the main target group of rectification education. All the experiences and lessons of the rectification movement are a valuable heritage of the purity and style of the party construction, and the eight provisions have the characteristics that are precise, scientific and sustainable, and transform the old constraints, old ideas. The psychology of "governance" and "change" reflects the affirmation of social groups to fight against corruption. The eight provisions as a valuable monitoring resource should achieve the optimal allocation and maximize the social marginal benefit. The Power of Chinese government and the activity has consisted. They are willing to make a difference. Members of the Political Bureau are the third energy of Chinese reform or economy.
\end{abstract}

\section{Keywords}

Big Data, Eight Provisions, Rectification Movement

\section{Introduction}

\subsection{Research Background}

To one person, a team and even a ruling party, the most wisdom thing is to have 
self-knowledge. The Communist Party of China, which has been carrying the cause of national rejuvenation and national prosperity, has a great responsibility and a daunting challenge under the changing history. Since 18th CPC National Congress, based on the "gradual reduction of corruption to the minimum level" and "building a clean political party" goal, the central government accelerates the anti-corruption, against not only high level cadres, but also low level cadres, and embodies the firm determination and confidence in the party. Self-innovation is a fine tradition of the Communist Party of China. Yan'an rectification in 1942, rectification campaign in 1950 and 1957, comprehensive rectification movement in 1983-1987 and three talks education activity in 1998, are the party rectification movements according to accurate judgment of existing situation, and have left behind the precious experience and wealth for future generations. We can see the rise and fall of history. The Communist Party of China has always been a very popular party who has learned from experience and lessons from history. Wherever the critical moment of the Chinese nation is, wherever it goes, the Communists will always be able to deal with the pulse of the country. Since entering the new era, in order to better preserve the fine traditions and styles of the Party, the 18th CPC National Congress has been encouraged by the great responsibility of the "Chinese Dream" and the national rejuvenation and carries out the Party's Mass Line Education Practice. Soon after, the Central Political Bureau has launched eight provisions on improving the work style and keeping close contact with the masses. "On improving the work style, close contact with the masses of the eight provisions", it concentrates on the outstanding problems in the construction of the party.

The eight provisions are the starting point of the party's mass line educational practice. From the academic point of view, the eight provisions are a new thing since 2013, so the relevant academic research is relatively small.

\subsection{Research Methods: Textualization-Building a Database-Full Sample Analysis}

Big data are not only a tool for researchers, but also should be internalized into the thinking of researchers. The typical case analysis or case comparative analysis is based on the subjective will of the researcher, which is not objective enough. "Sampling analysis in the era of big data is like riding a horse in the automotive era. Big data era, sample = total" [1]. Big data are a collection trace data of online, full sample and interactive. Big data make predictions based on the overall sample data analysis and large-scale data analysis.

This research is based on the concept of the full sample of big data. The research method is mainly embodied in the following aspects: text data, small database, data classification analysis, theoretical abstraction. 1) Data collection. In this paper, the eight provisions investigate data collected between 2015 and July 2016 in a comprehensive and accurate way, forming a 19-month calendar of research space. The data are all based on the authority of the release: the Central Commission for Discipline Inspection Ministry of Supervision official website 
announced violations of the eight provisions of the monthly report." We should continue to adopt the way of traditional methods of collecting data for specific needs and we also must be good at using the modern network information technology and various data sources to collect all relevant data." [2] 2) Text data and the construction of small case database. Based on the eight provisions of the monthly report, this paper extracts data and text information into data. According to the research design of various types and dimensions of classification statistics, it forms the small database of eight provisions. This database is not a sample data, but constitutes a full sample data structure for 19 months, so the reliability and validity of the data is very high and the theoretical analysis is based on a solid and credible sample structure. 3) Extraction of data from the case database. This paper calculates the data by the formula, and compares and analyzes the data based on the various dimensions. 4) Based on the data analysis, theoretical and logic level, the eight provisions and party's rectification movement are unified into the theme of "hope" and "change", but this paper mainly analyzes eight provisions that are scientific relative to the latter one, and further refines the theoretical core and characteristics of the Party's construction since the 18th CPC National Congress.

\section{Empirical Evaluation of the Eight Provisions}

The effectiveness of the eight provisions can be evaluated from three perspectives. First, the characteristics of the prosecution and punishment, which is investigated the highest frequency, which is the lowest frequency, what is the reason? Second, the overall investigation of the eight provisions of the diachronic trend, that is, dynamic performance evaluation. Third, the administrative level, that is, the distribution of cadres at the provincial, prefectural, county, and township level violated the eight provisions. This paper evaluates eight provisions from these three perspectives on its effectiveness and implementation, and strives to dig the reasons behind the figures, to pave the way for the logical analysis.

\subsection{First Perspective: To Investigate the Characteristics of the Activity}

According to the data sorting and cartography analysis, we can see, from 2015 to July 2016, the violation numbers of eight provisions problems, people, Party disciplines are very different, and we can also find the rule after careful review. It can be seen from Figure 1, the number of illegal allowances and subsidies or welfare, illegal use of official vehicles, illegal gifts or cash gifts, illegal use of public funds occupy a considerable proportion. Among them, the illegal allowances and subsidies or welfare has the largest number, the number of cases investigated and dealt with accounted for $23.8 \%$, the number of Party discipline accounted for $28.1 \%$, up to 19,060 people; the number of illegal use of official vehicles accounted for $22.8 \%$, Party discipline accounted for $15.7 \%$ of the number of people, up to 15,904 people; the number of illegal gifts or cash gifts cases in- 


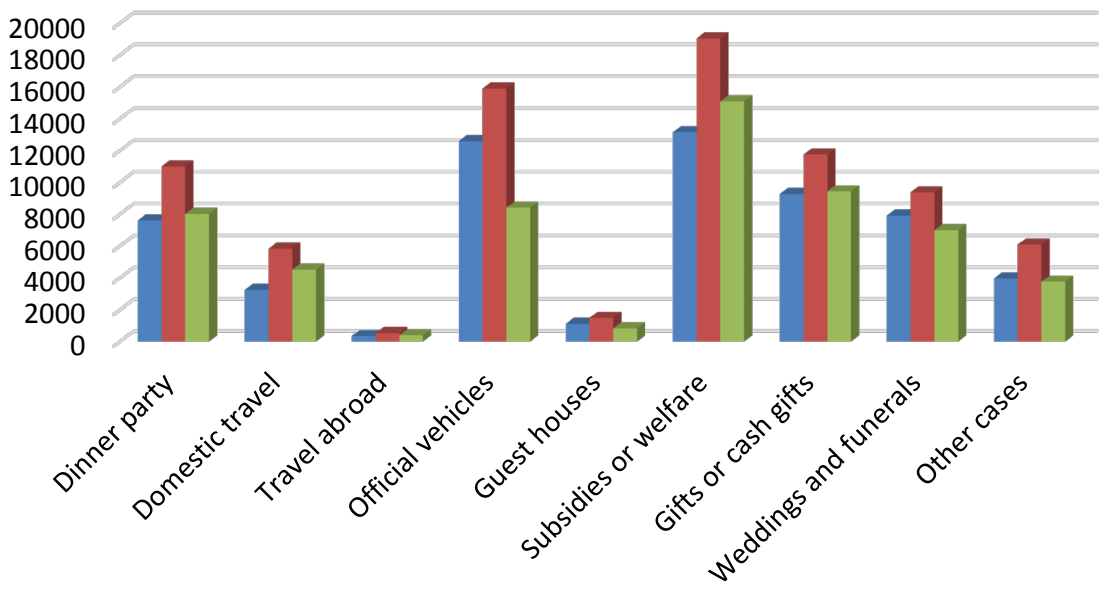

Numbers of investigated people $\square$ Numbers of Stettled $\square$ Numbers of party discipline

Figure 1. Investigation and distribution of eight types.

vestigated and dealt with accounted for $16.8 \%$, the number of people punished accounted for $17.6 \%$, up to 11,759 people; the number of illegal use of public funds cases investigated and dealt with accounted for $13.8 \%$, the number of people punished accounted for 15\%, up to 11,008 people.

Why are these four provisions investigated and dealt with officials in high-risk areas? First, the four provisions related to the economic interests of cadres. Illegal subsidies, illegal use of official vehicles and funds, etc., will reflect the status and power of cadres with low consciousness. They tend to think it's the so-called return performance. Second, the legal system of socialist market economy is not perfect, many human social habits, such as "gratitude", "reciprocity" exists in daily life. But once infiltrated into the political and economic life, it is likely to lead to corruption.

Belong to the high-risk areas of the four investigated problems are the same with early days of the founding. Some party members and cadres do not seek progress, love leisure and hate labour, and abuse of power to pursue their own interests. Positional party members are less susceptible to bad habits.

\subsection{Second Perspective: Diachronic Trend of Eight Provisions}

There are three types' results of eight provisions investigating: problem investigation, Processing personnel, party discipline. We can establish three indicators accordingly: To investigate the number of problems, the number of processing personnel, the number of Party discipline. This paper observes the implementation diachronic trends of eight provisions from these three indicators. As can be seen from Figure 2, from January 2015 to July 2016, the three indicators have experienced rising, rising slowly, reaching the peak and then high-speed decline, rising, reaching the peak, and then decline in its trend. This perspective reflects the dynamic performance of the eight provisions governing.

From January to June 2015, the investigated number of eight provisions shows rapid growth, during July to October, shows slow rise, in November reached a 


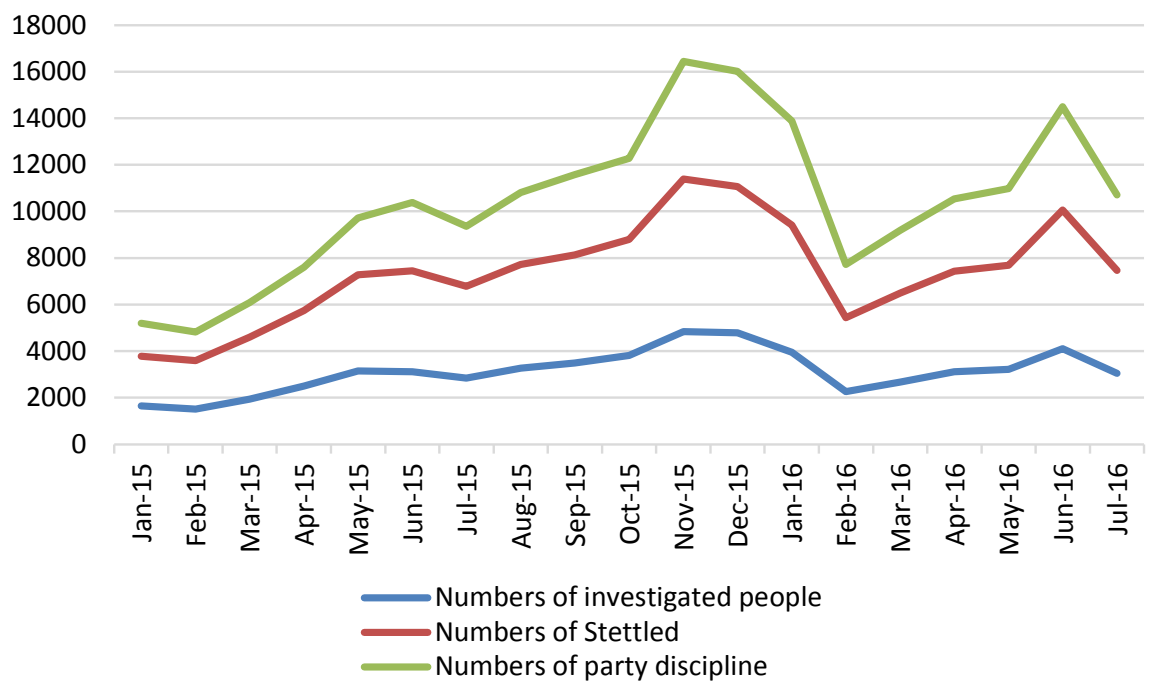

Figure 2. Diachronic trend of eight provisions.

peak (investigated number reached 6565 people). After the end of December 2015, the investigated number shows significantly down, in February 2016, the number of investigated people from the peak 6565 down to 3180 people. From February 2016 to June the same year, the number of investigation increased significantly month by month, in June 2016 reached the peak of 5959 people. What are the reasons for these data? First, from the specific analysis of the illegal allowances and subsidies or welfare, and illegal gifts or cash gifts at the end of 2015 to early 2016, we can find that November, December, January have the largest investigated number, both reached its peak In December 2015 (Figure 3). Since the implementation of the eight provisions, the central and local authorities at all levels to fix the program, the annual meeting has been greatly reduced, but the annual subsidies and welfare behavior is still uncommon. Although the benefits of the specification may not be as high as usual, which is also contrary to the original intention of the eight provisions. A large number of investigated cases indicate the seamless, uninterrupted efficacy of eight provisions.

Any policy or regulations from the introduction to the implementation effect, that the system changes are few can be immediate, there is a "time lag" [3] effect, will generally experience this process: Policy making - initial implementationwait and see-full implementation-effectiveness. The implementation process of the eight provisions also conforms to this rule: 1) In the early implementation of the eight provisions, the central government based on the top-level design, from top to bottom to promote the eight provisions. Although the effective force to deal with some irregularities, some cadres are in the state of wait and see. 2) By the medium-term of implementation, the central attitude is clearer, investigation efforts continue to increase and the number of investigated people increases rapidly. Government officials as a political rational man, while recognizing that the eight provisions is not a gust of wind movement, but a continuous high voltage line, so as to gradually change the understanding and obey the rules. 3) In the latter part of the implementation, the deterrent effect of the 


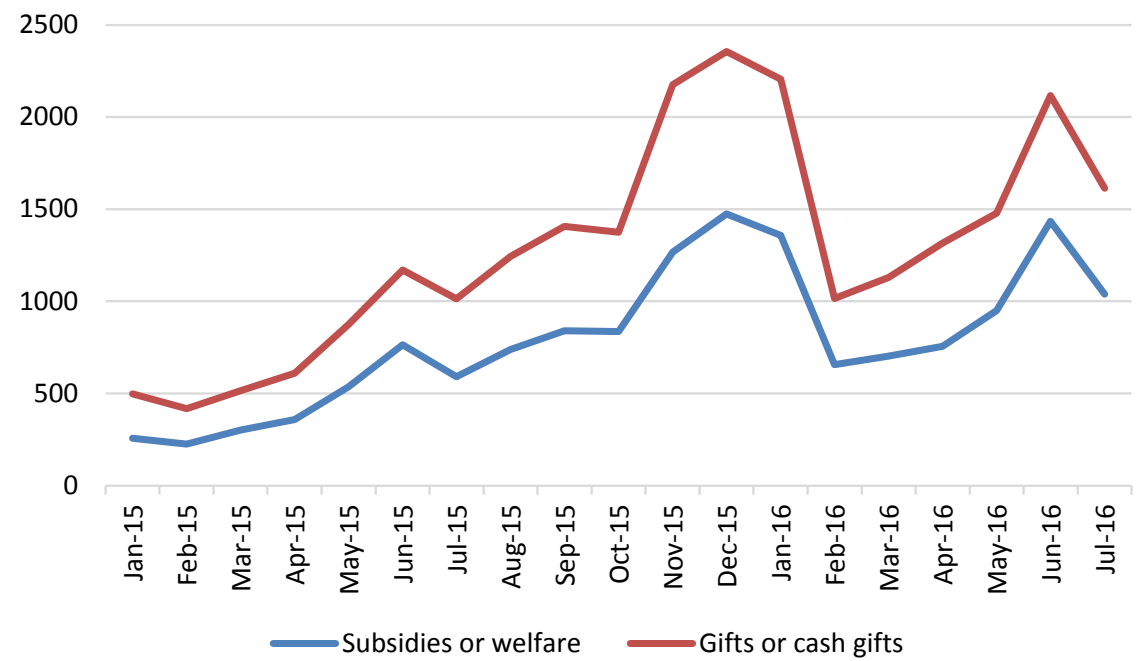

Figure 3. Diachronic trend of two provisions.

eight provisions initially shows up. In the continuous anti-corruption situation, leading officials at all levels dare not, can't, don't want to rot, the situation initially formed. Correspondingly, the number of investigated cases and people began to fall significantly (Figure 4).

\subsection{Third Perspective: Administrative Level of Investigated Cadres}

Everyone is equal before the eight provisions. Eight provisions investigation covers: the provincial, prefectural, county and township level cadres of the party and the government. From the administrative level distribution, we can see, January 2015 to July 2016, 14 provincial and ministerial level cadres investigated; 903 people investigated from prefectural, accounting for 1\%; 7278 people investigated from county level, accounting for $9 \%$; 71,718 people investigated from township level, accounting for $90 \%$. From the data available, the administrative level of the leading cadres and the number of people being investigated into a significant negative correlation, that is, the higher the level of the number of people being investigated, the lower the number of people being investigated (Figure 5).

How can this be explained? There are four reasons for this. First, relative to the provincial, prefectural, county level, township level has the largest number of cadres, and the probability of being investigated is high. Second, township cadres mostly work in the county, township and village level units, their working environment more affected by social rules than system and law, hinder the formation of new rules and promotion of awareness. Third, the lag of information transmission. The township cadres work at the grass-roots level, the eight provisions convey from top to bottom, the formation of energy transmission losses. So the policy implementation is lagging behind, grass-roots officials take chances, and thus become the worst disaster areas. Fourth, from an objective point of view, part of the township level cadres understand the spirit of the central spirit and 

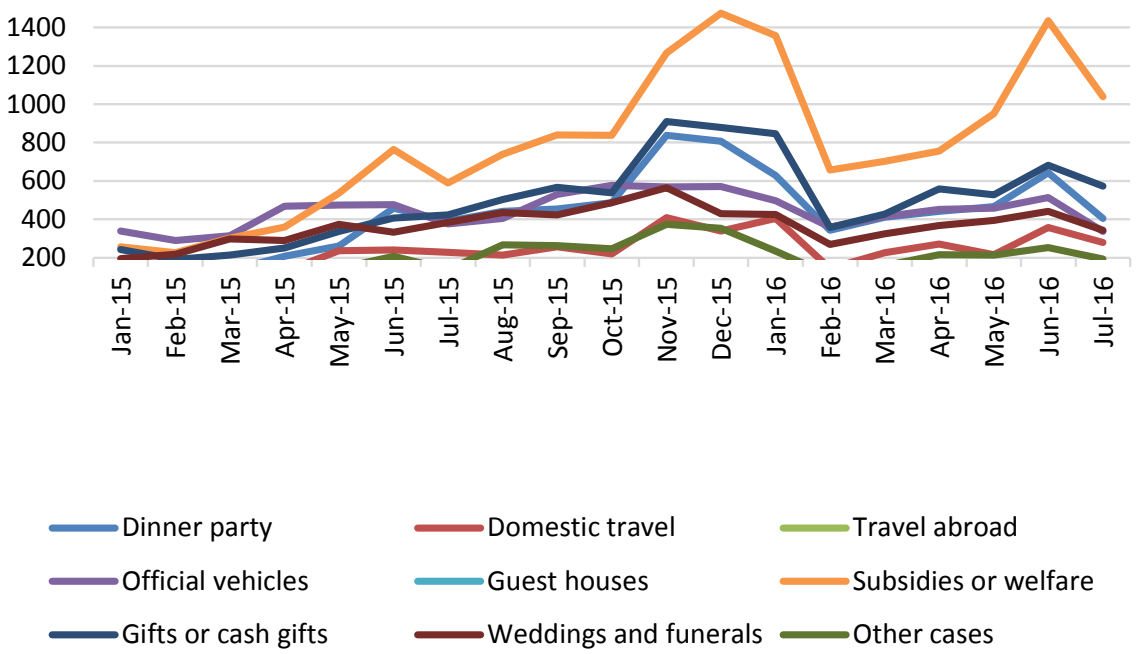

Figure 4. Diachronic trend of party disciplines.

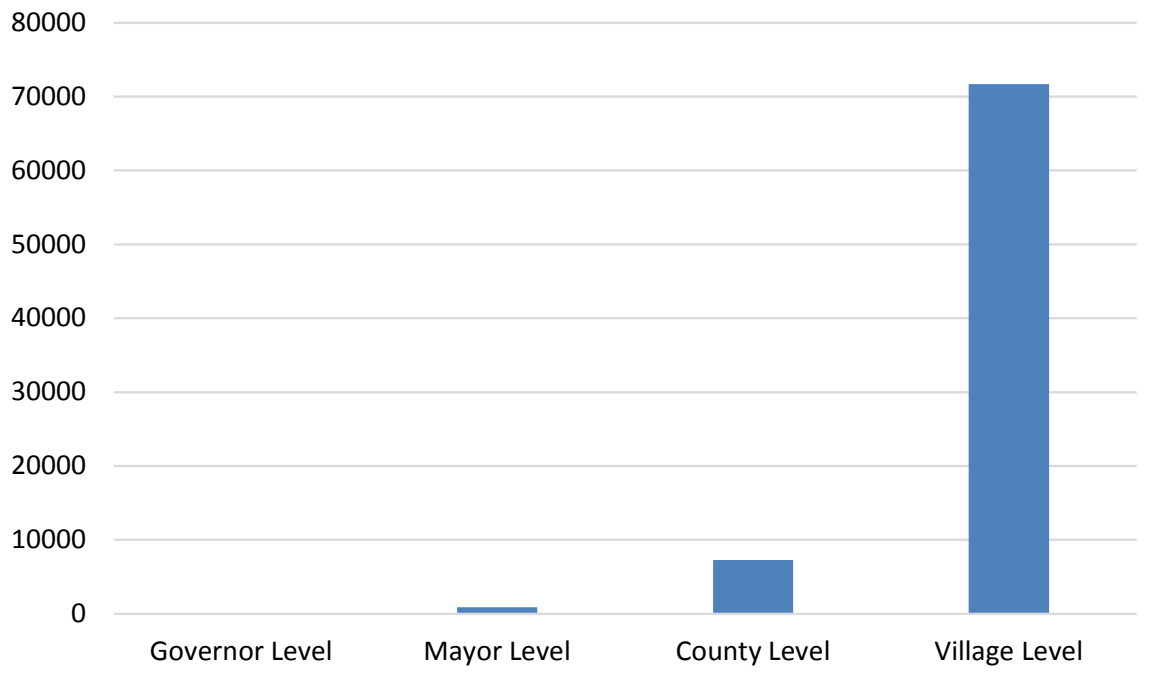

Figure 5. Distribution of administrative level of investigated cadres.

quality, but also relatively low. In addition, party's style of construction is taken "low center of gravity" remediation strategy model. Cadres around the masses are the foundation of governance.

\section{Logical Analysis of Rectification Perspective}

\subsection{Accuracy of the Eight Provisions}

The rectification movement of the Communist Party of China has always been very targeted, find the problem to the disease can be done. For example, after rectification in 1951-1953, a total of 328,000 people left the party organization, which belongs to all kinds of bad elements are 238,000 , more than 90,000 unqualified members voluntarily or been advised to quit the party.

From 1983 to 1987, in order to eliminate the pernicious influence of Cultural Revolution and restore the purity of the party, China Policy Committee and Deng Xiaoping organized comprehensive rectification movements. The move- 
ment is divided into three stages, covering from the central ministries and provinces district level, county level leading cadres to rural community level. In 6 years, a total of 177 thousand people expelled from the party.

During 19 months, the proportion of rural party and government cadres investigated more than 70,000 people, accounting for up to $90 \%$ (Figure 6). With the Central Commission Discipline Inspection of the popular anti-corruption movement echoes, the main intention of the eight provisions may therefore reflect: the township level cadres are the tentacles of national administrative system of cadres, and close to the masses. The township cadres in this key position reflect the probity of party and government and serve the people.

With the strict implementation of the eight provisions at the grassroots level, the number of township-level investigated fell from the peak of 5919 people (November 2015) to 2819 people (in February 2016), the decline rate reached $52 \%$ (Figure 7). The number of Investigated cases and people changes in one after another, reflects the consciousness awakening of dare not, can't, don't want

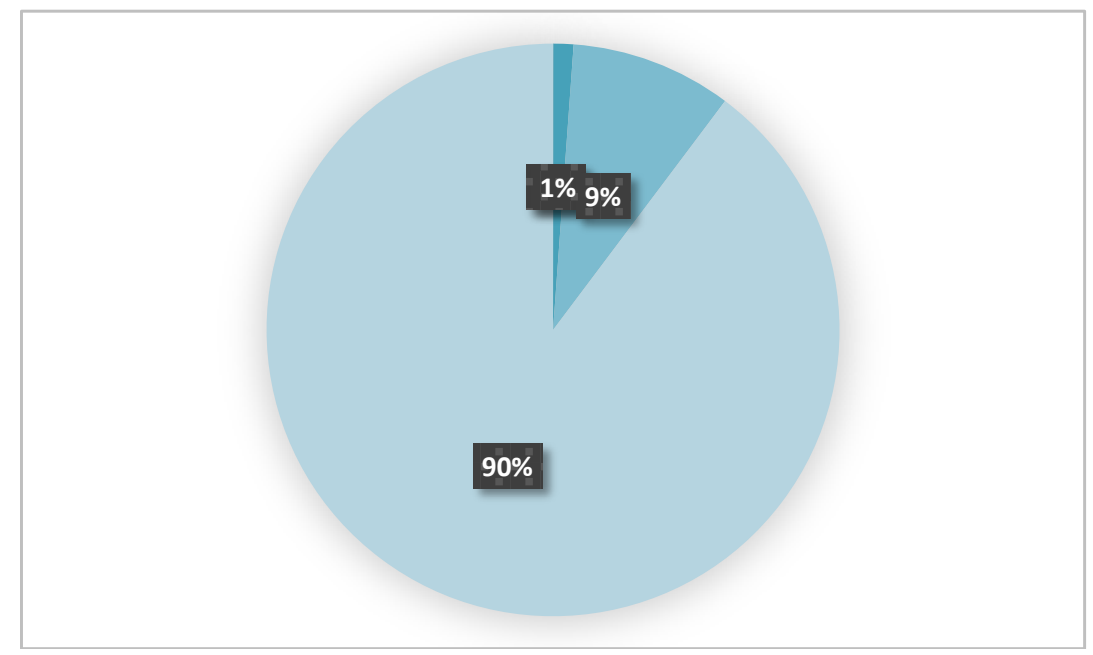

Figure 6. Proportion of investigated administrative level.

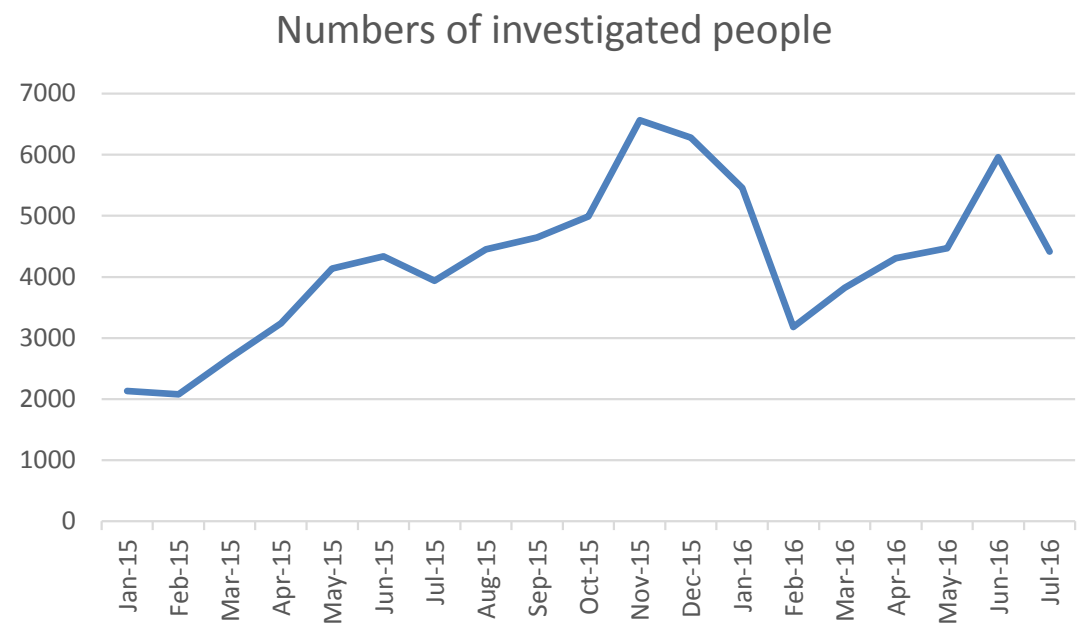

Figure 7. Trends of the number of investigated township level cadres in 2015-2016.7. 
to rot. "[4] Good system can make the bad guys can't be arbitrary, the bad system can make good people can't do a good deed, and even to the negative." The eight provisions have a significant effect on promoting governance of the grassroots cadres. Moreover, Chinese anti-corruption constitute an organic system: warning constitute the first line of defense to prevent the corruption, the eight provisions constitutes the second line of initial corruption, the judicial review has become the third line of defense, thus forming a synergistic effect of $1+1+$ $1>3$.

\subsection{The Science of the Eight Provisions}

The party's rectification movement is not to punish some people or a group, but for the party's self-innovation. Style construction is a tool; the purpose is to return to the party's fine tradition, forming good government and morals. Firstly, we should focus on learning theory to improve awareness, and then openly find the problem, and then seriously responsible for criticism and self-criticism, and ultimately find problems and solve problems, overcome other ideas, and form a unified correct thinking. For the work style, achieve the purpose with a scientific way and methods.

Throughout the history of the party several successful rectifications, although the situation and tasks is different, the way and the time limit are different, but all are right antidote against the disease. Such as the Yan'an rectification movement lasted for 4 years, took "learn from past mistakes to avoid future ones" as purpose and principles of rectification, aimed at three bad styles, mobilized nearly two-thirds of party members and cadres to promote the process of Marxism in China; In 1950, the movements against the "three evils" and the "five evils" began to rectify the party's grassroots organizations as the main task, which lasted four years and examined about one-tenth of the unqualified party members. According to statistics, about 600,000 party members and cadres left the organization because of various problems, and educated and cultivated a number of new party members; In 1983 the rectification in the party aimed at ideology, style, organization impure, and lax discipline and other issues, in order to rectify the style, unity of thinking, strengthen discipline, mobilize the masses to participate the registration of Party members and organizations, expelled nearly 30 thousand people from the party, Which lasted three and a half year and laid a solid foundation for the reform and opening up of the party leadership; In 1998, under the new situation of the construction of the party, "three emphases", i.e. "emphases on theoretical study, political awareness, and moral integrity" were carried out for some party cadres and cadres to ignore the problems of theoretical study, and the prevalence of bureaucracy and formalism. In 2 years, mobilized 5 million cadres and the masses to participate in the study and help the rectification, 700,000 leading cadres at and above the county level to participate in the study and education. The situation, problems, tasks of party's previous rectification movement are not the same, but the previous rectification comes down in one continuous line. 
Eight provisions aim at the old bureaucracy, "jack-in-office", backward consciousness and bad customs long-term infiltration into the political, economic life. In the rectification movement in 1957, the bureaucracy was the main target. When a system has not yet been formed in the country, social customs or rules maintain the stability of social order. One of the common ideas of modern society is that customs and rules cannot solve all problems, but to some extent, they simplify life. When the state system is becoming more and more perfect, the concept of the rule of law is popular, the old and new rules will be intense friction, in line with the requirements of the times will be supplemented or strengthened, the reverse will be replaced or modified [5]. "The officer will not make a fortune, and can't do business; you can't have it both ways. These are the vehicle running on two roads." In political life, especially in the work of administrative personnel, we must take a careful look at social customs and rules. The eight provisions is a system that restricts the behavior of cadres. We should discard the dross, preserve its essence, retain the fine tradition of culture, abandon the rules that are not conducive to the work of party and government.

As the new China began to explore and construct the socialist rule of law on the basis of the long feudal rule, the socialist market economic system is not perfect. Some of the party and government cadres occupy illegal money by virtue of their power and national resources. This shows that party members have a weak sense of law and party. Dripping water wears through a stone. Accumulation of these countless small and specific changes on the whole constitutes a fundamental institutional change [3]. The competition of national strength depends largely on the survival of the fittest system, in addition to the transformation of social customs, eight provisions as the ruling party self-precipitation and innovation system, its vitality lies in the implementation and its effectiveness lies in lasting.

\subsection{Sustainability of the Eight Provisions}

A policy or the implementation of the system also can't escape the law of diminishing marginal effect; the initial policy effect is significant but with the changing of the social environment, coupled with the inertia of the policy, the original policy effectiveness inevitably shrinking.

From the content point of view, the past rectification movement were around the issue of history, now the party's mass line educational practice, although the purpose is to control the current and past style construction problems, from the contents of the eight regulations, it's different from the past, the rectification movement is sustainable with the long-term impact. Why? Eight provisions correct the cadre's long-term mistakes at all levels of the party and government, and Figure ht against corruption. The implementation of the eight provisions is beneficial to all levels of leading cadres and the masses.

Some bad or inappropriate social customs to penetrate into the field of political life has become the shackles, and are corrupting cadres of party and government. Although some cadres due to the so-called reputation or their own pro- 
motion, it is difficult for them to make the right choice. On the other hand, people who need public service, run a few departments, meet different leaders and send a few gifts are extremely common. Administrative staff and the masses bear the cost due to bad customs.

Any choice will cost. Eight provisions is strict party discipline, and also is system weapon of strict official governance. Under the pressure of the system, the cost of corrupt behavior cadres continues to increase. The ultimate beneficiaries of all levels of units and leadership style improvement are the broad masses of the people.

In summary, the cost of the all sides is greatly reduced due to the implementation of the eight provisions. Adhere to the provisions of the eight, put an end to bad customs and the shackles of human society, so that the people and cadres can make a rational and correct choice. The lasting reduction of the total cost has a considerable effect on overcoming the diminishing marginal returns of the eight provisions. The vitality of the system lies in the implementation of the law of diminishing marginal returns is conducive to the sustainable development of the eight provisions, more conducive to the construction of the party's work style has been continuously strengthened.

\section{Summary and Reflection: "Hope" and "Change"}

Eight provisions, as the new rectification movement of the era, not only achieved a stage victory, but also won the hearts of the people. Based on the data from 2015 to July 2016, this paper analyzes the effectiveness and implementation of the eight provisions from three perspectives. Through analysis of data we found:

1) First, eight provisions investigated the characteristics of the problem that was directly related to economic interests of leading cadres. Illegal subsidies and illegal use of official vehicles constitute a direct violation; second, most of the problems were related to social customs penetration into the political life.

2) The investigated number and administrative levels showed a significant negative correlation: the lower the administrative level, the more the number of investigation, and the eight provisions constitute a low administrative levels center of anti-corruption strategy.

3) In the ongoing severe anti-corruption situation, grass-roots government officials gradually change behavior expectations, from wait-and-see changing to follow the rules.

\section{References}

[1] Meyer-Schoenberg, V. and Cookier, K. (2013) Big Data: A Revolution That Will Transform How We Live, Work and Think, Zhejiang People's Publishing House, Hangzhou, 23.

[2] Li, J.C. (2014) Big Data and New Mind on Statistics. Statistical Research, 1-12.

[3] Coase, R. and North, D. (2004) Property Rights and Institutional Changes. Shanghai People's Publishing House, Shanghai, 31.

[4] Xi, J.P. (2015) Xi Jinping's Speech at the Eighteen Plenary Session of the Central- 
Commission for Discipline Inspection of the Fifth Plenary Session. http://www.cpc.people.com.cn/n/2015/0114/c64094-26380006.html

[5] He, S.L. (2014) Experience and Enlightenment of the Party's Rectification Movement. Journal of Chongqing University of Education, No. 4, 5-7.

Submit or recommend next manuscript to SCIRP and we will provide best service for you:

Accepting pre-submission inquiries through Email, Facebook, LinkedIn, Twitter, etc. A wide selection of journals (inclusive of 9 subjects, more than 200 journals)

Providing 24-hour high-quality service

User-friendly online submission system

Fair and swift peer-review system

Efficient typesetting and proofreading procedure

Display of the result of downloads and visits, as well as the number of cited articles Maximum dissemination of your research work

Submit your manuscript at: http://papersubmission.scirp.org/

Or contact jss@scirp.org 